\author{
MARIUSZ LISKOWSKI \\ Uniwersytet Mikołaja Kopernika w Toruniu \\ mariuszliskowski@wp.pl
}

\title{
Pojęcie wynagrodzenia za pracę w Kodeksie pracy
}

\section{The concept of the remuneration for work in the Labour Code}

\begin{abstract}
Streszczenie. Niniejszy artykuł stanowi próbę ukazania istoty pojęcia wynagrodzenia za pracę w świetle obowiązującej regulacji prawnej, przede wszystkim przepisów Kodeksu pracy. W opracowaniu analizie poddano poszczególne cechy charakterystyczne dotyczące tytułowego zagadnienia, które zestawiono z innymi świadczeniami niż wynagrodzenie za pracę. $Z$ uwagi, że Kodeks pracy nie zawiera legalnej definicji wynagrodzenia za pracę, autor wskazuje na sposób normatywnego ujęcia omawianego zagadnienia, jak również formułuje inne propozycje zmian de lege ferenda.
\end{abstract}

Słowa kluczowe: praca; wynagrodzenie za pracę; płaca; zarobek.

\begin{abstract}
This article attempts to present the essence of the term of remuneration for work in the light of binding regulations, primarily in the Labour Code. The study contains an analysis of the main distinguishing features of the subject matter along with a comparison of compensation and other benefits provided in Polish law. Considering the lack of legal definition of remuneration for work, the author examines the normative interpretation of the term and submits some changes de lege ferenda in the field of the subject matter.
\end{abstract}

Keywords: work; remuneration for work; salary; earnings.

\section{Uwagi wprowadzające}

Przedmiotowe opracowanie ma na celu przedstawienie istoty wynagrodzenia za pracę przede wszystkim w ujęciu Kodeksu pracy ${ }^{1}$. Analizie zostanie poddana regulacja prawna zawarta w dziale trzecim Kodeksu, szczególnie zaś Rozdział Ia Wynagrodzenie za pracę. W niniejszym opracowaniu zostanie dokonana analiza przepisów de lege lata, jak również propozycje zmian de lege ferenda.

Wydaje się, że zmiany, które nastąpiły na przestrzeni lat $\mathrm{w}$ stosunkach pracy, doprowadziły do zerwania z koncepcją wynagrodzenia jako płacy, której pierwowzorem była

Ustawa z dnia 26 czerwca 1974 r. Kodeks pracy (tekst jedn.: Dz.U. z 2014 r. poz. 1502 ze zm.), dalej jako k.p., Kodeks, regulacja Kodeksowa. 
wywodząca się z prawa rzymskiego konstrukcja - locatio conductio operarum - najem pracy $^{2}$. Wówczas płaca była postrzegana jako cena za pracę, zaś praca ludzka jako towar. Współcześnie koncepcja wynagrodzenia za pracę jest szeroka i obejmuje swym zakresem także te świadczenia, które otrzymuje pracownik jako uzupełnienie wynagrodzenia (np. udział w zyskach przedsiębiorstwa pracodawcy) bądź jako substytut wynagrodzenia (np. korzyści otrzymywane mimo niewykonywania pracy) ${ }^{3}$. Zatem z jednej strony występuje nadal zależność wykonanej pracy przez pracownika i zapłata za nią, co nawiązuje do koncepcji płacy. Z drugiej jednak strony występują przewidziane w przepisach prawa wypłaty, które nie odwzajemnią wykonanej pracy.

Odrębnego rozważenia wymaga kwestia rozumienia wynagrodzenia za pracę. W tym miejscu należy zastanowić się, jak należy ująć omawiane zagadnienie, czy poprzez definicję ${ }^{4}$, czy może poprzez wskazanie cech charakterystycznych odnoszących się do tego pojęcia. W literaturze przedmiotu brak bowiem jednolitego stanowiska odnoszącego się do sposobu ujęcia wynagrodzenia za pracę. Niektórzy autorzy definiują wynagrodzenie za pracę poprzez kryterium przedmiotu ${ }^{5}$, inni budują definicję nominalną ${ }^{6}$, czy odnoszą się do zespołu cech składających się na to pojęcie ${ }^{7}$. Wydaje się, że najlepszym sposobem zdefiniowania wynagrodzenia za pracę będzie definicja wskazująca cechy charakterystyczne omawianego pojęcia. Zważyć bowiem należy, że przepisy Kodeksu nie zwierają legalnej definicji wynagrodzenia za pracę, ale w wielu miejscach odnoszą się do omawianego pojęcia, ukazując jego cechy charakterystyczne. Kodeks wskazuje na takie cechy wynagrodzenia za pracę, jak: wzajemność (art. 22), periodyczność (art. 85), obowiązkowość (art. 94). Nadto przepisy Kodeksu kształtują zasady odnoszące się do wynagrodzenia za pracę: godziwości (art. 13), prawa do jednakowego wynagrodzenia (art. $18^{3 \mathrm{c}}$ ), związane z ustalaniem i kształtowaniem wynagrodzenia (art. $77^{1}$ i n., art. 78), czy wreszcie wskazując na ochronę wynagrodzenia za pracę (art. 84 i n.). Nadto, definicja ukazująca wynagrodzenie za pracę poprzez cechy charakterystyczne, pozwoli odróżnić wynagrodzenie za pracę od innych świadczeń, uregulowanych w Kodeksie pracy.

Poza prawem pracy wynagrodzenie za pracę występuje również w innych naukach

\footnotetext{
Zob. K. Kolańczyk, Prawo rzymskie, Warszawa 2007, s. 398 i n.

Tak M. Seweryński, Wynagrodzenie za pracę. Pojęcie, regulacja i ustalanie, Warszawa 1981, s. 38 i n.

Zob. T. Kotarbiński, Elementy teorii poznania, logiki formalnej i metodologii nauk, Wrocław-WarszawaKraków-Gdańsk-Lódź 1990, s. 51 i n.

5 Zob. M. Święcicki, Prawo wynagrodzenia za pracę, Warszawa 1963, s. 27 i przywołaną tam literaturę.

6 Por. W. Szubert, Zarys prawa pracy, Warszawa 1963, s. 240; L. Florek, T. Zieliński, Prawo pracy, Warszawa 2007, s. 184; T. Liszcz, Prawo pracy, Warszawa 2014, s. 282.

7 M. Seweryński, Wynagrodzenie..., s. 82 i n.
} 
prawnych (m.in. w prawie ubezpieczeń społecznych, prawie handlowym czy prawie upadłościowym). O wynagrodzeniu mowa jest także $\mathrm{W}$ naukach pozaprawnych (m.in. ekonomii czy naukach socjalnych). Ogólnie można powiedzieć, że każda z przywołanych dziedzin nadaje swoiste znaczenie omawianemu pojęciu, które odbiega od tego z Kodeksu pracy ${ }^{8}$.

\section{Wynagrodzenie za pracę w Kodeksie pracy}

Wstępna część Kodeksu formułuje zasadę - prawa do godziwego wynagrodzenia, realizowanego przez przepisy prawa pracy, jak również politykę państwa w dziedzinie płac, W szczególności poprzez ustalanie minimalnego wynagrodzenia za pracę (art. 13 k.p.). Regulacja Kodeksowa nie wskazuje, jak należy rozumieć istotę godziwości wynagrodzenia za pracę, nie czyni tego również żaden przepis prawa krajowego ani systemy pozakrajowe. W słowniku języka polskiego "godziwy" znaczy tyle, co odpowiedni, właściwy, słuszny, rzetelny ${ }^{9}$. W kontekście wynagrodzenia wypada jeszcze dodać - sprawiedliwy. Są to zatem zwroty bardzo ogólne o charakterze niedookreślonym, którym można nadać dowolną treśćc ${ }^{10}$.

Stwierdzić należy, że z treści art. 13 k.p. wynika przede wszystkim zobowiązanie po stronie państwa do podjęcia działań mających na celu realizację tego prawa. Wydaje się, że jest to ciągle zasada bardziej w znaczeniu postulatywnym niż normatywnym, choć od wprowadzenia tego przepisu w życie minęło już 20 lat ${ }^{11}$. Do takiej konstatacji można dojść, bacząc na działania dotychczas podjęte przez ustawodawcę w celu realizacji omawianej zasady, na gruncie ustawy o minimalnym wynagrodzeniu za pracę $^{12}$ i wyrażonej krytyki $\mathrm{w}$ literaturze przedmiotu związanej $\mathrm{z}$ poziomem minimalnego wynagrodzenia $\mathrm{w}$ naszym $\mathrm{kraju}^{13}$. Zasadę godziwego wynagrodzenia można postrzegać jako "klimat"14, kierunek, w którym winno dążyć państwo, do wypracowania standardów, aby wynagrodzeniu za pracę można było przypisać cechy, o których była mowa, w ujęciu słownika języka polskiego.

8 Zob. M. Nowak, Wynagrodzenie za pracę, red. Z. Góral, Warszawa 2014, s. 11. Szerzej na temat wynagrodzenia w ekonomii: M. W. Kopertyńska, Motywowanie pracowników. Teoria i praktyka, Warszawa 2009, s. 99 i n. oraz przywołana tam literatura, natomiast odnośnie nauk socjalnych zob. M.B. Rycak, E. Wronikowska, A. Rycak, Prawo pracy repetytorium, Warszawa 2012, s. 172.

9 Zob. E. Sobol, Nowy słownik języka polskiego pwn, Warszawa 2002, s. 234.

10 Zob. J. Skoczyński, Prawo do godziwego wynagrodzenia, „Praca i Zabezpieczenie Społeczne” 1997, nr 4, s. $11 \mathrm{i} \mathrm{n.}$

11 Dyspozycja art. 13 została zmieniona na mocy art. 1 pkt 14 ustawy z dnia 2 lutego 1996 r. o zmianie ustawy - Kodeks pracy oraz o zmianie niektórych ustaw (Dz. U. Nr 24, poz. 110) z mocą obowiązującą od dnia 2 czerwca $1996 \mathrm{r}$.

12 Ustawa z dnia 10 października 2002 r. o minimalnym wynagrodzeniu za pracę (Dz. U. Nr 200, poz. 1679 ze $\mathrm{zm}$.).

13 Zob. J. Wratny, Minimalne wynagrodzenie za prace - nowe regulacje prawne, „Praca i Zabezpieczenie Społeczne" 2003, nr 6, s. 2 i n., T. Liszcz, Prawo pracy, Warszawa 2014, s. 276.

14 Zob. J. Piątkowski, Aksjologiczne i normatywne podstawy prawa stosunku pracy, Toruń 2013, s. 162 i przywołana tam literatura. 
W tym kontekście dążyć należy do zapewnienia minimalnemu wynagrodzeniu za pracę poziomu, o którym mowa w regulacji międzynarodowej, zwłaszcza Europejskiej Karcie Społecznej (art.4) i wypracowanej wykładni tego przepisu przez Komitet Niezależnych Ekspertów $^{15}$.

Wynagrodzenie za pracę jest bardzo istotnym elementem stosunku pracy (art. $22 \S 1$ k.p.). Kodeks pracy expressis verbis stanowi o odpłatnym charakterze stosunku pracy, co wyróżnia stosunki pracy od stosunków cywilnoprawnych ${ }^{16}$. Powyższe determinuje obowiązki po stronie pracodawcy do terminowego i prawidłowego wypłacania pracownikowi wynagrodzenia (art. 94 pkt 5 k.p.). Uprawnienie pracownika do otrzymania wynagrodzenia za pracę wynika z nawiązanego stosunku pracy. Stosunek pracy jest zatem warunkiem sine qua non do nabycia roszczeń w przedmiocie wypłaty wynagrodzenia za pracę.

Tytuł działu trzeciego Kodeksu Wynagrodzenie za pracę $i$ inne świadczenia sugeruje, że na gruncie regulacji Kodeksowej występują co najmniej dwa rodzaje świadczeń wynikających ze stosunku pracy: wynagrodzenie za pracę oraz inne świadczenia.

Przepisy Kodeksu przede wszystkim w Rozdziale Ia. Wynagrodzenie za prace działu trzeciego odnoszą się do wynagrodzenia za pracę. Wynagrodzenie za pracę ma W szczególności odpowiadać rodzajowi wykonywanej pracy i kwalifikacjom wymaganym od pracownika oraz uwzględniać ilość i jakość świadczonej pracy (art. 78 § 1 k.p.). Zważyć należy, że przedmiotowa regulacja nie zawiera enumeratywnego wyliczenia, określa jedynie przykładowe przesłanki do ustalenia wysokości wynagrodzenia. Na kryteria te musi baczyć pracodawca przy ustalaniu wynagrodzenia, zaś inne przesłanki może uwzględnić. Tym samym pracodawcy mogą stosować inne "dodatkowe" kryteria przy ustalaniu wysokości wynagrodzenia za pracę, mając na względzie jednak, co najmniej by nie miały one charakteru dyskryminacyjnego (art. $18^{3 \mathrm{c}}$ i n. k.p.) oraz były zgodne z poziomem, o którym mowa $\mathrm{W}$ ustawie o minimalnym wynagrodzeniu za pracę.

$\mathrm{Z}$ analizy treści art. 80 zd 1. k.p. w zw. z art. 22 § 1 k.p. wynika, że wynagrodzenie za pracę jest świadczeniem wypłacanym przez pracodawcę na rzecz pracownika, za pracę wykonaną. Wskazać należy, że praca powinna zostać wykonana niewadliwie lub nawet wadliwie, ale z przyczyn niezawinionych przez pracownika (art. $82 \S 1$ k.p.). Praca winna

15 Europejska Karta Społeczna sporządzona w Turynie dnia 18 października 1961 r. (Dz.U. z 1999 r. Nr 8, poz. 67). Polska jednak nie jest związana postanowieniami art. 4 ust. 1 Karty. Zob. G. Goździewicz, Refleksje na temat prawa do godziwego wynagrodzenia za pracę, w: Wynagrodzenie za pracę w warunkach społecznej gospodarki rynkowej i demokracji, red. W. Sanetra, Warszawa 2009, s. 64 i n.

16 Zob. art. 735 § 2 ustawy z dnia 23 kwietnia 1964 r. Kodeks cywilny (tekst jedn.: Dz. U. z 2016 r., poz. 380 ze $\mathrm{zm}$.). 
zostać wykonana $\mathrm{w}$ sposób sumienny i staranny, zgodnie $\mathrm{z}$ poleceniami przełożonego (art. $100 \S 1$ k.p.). Wydaje się, że obowiązkowi sumiennego i starannego wykonywania pracy przez pracownika w odniesieniu do wynagrodzenia za pracę, można przypisać charakter lex imperfecta. Żaden przepis Kodeksu bowiem nie wskazuje, że w przypadku braku sumienności czy staranności ze strony pracownika, wynagrodzenie za pracę nie przysługuje. Wynagrodzenie za pracę jest świadczeniem przysługującym pracownikowi za pracę prawidłowo wykonaną, zgodnie $\mathrm{z}$ wytycznymi pracodawcy. Jest to świadczenie wzajemne w stosunku do pracy wykonanej przez pracownika.

Dyspozycje norm art. 85 i 86 § 2 k.p., choć objęte są Rozdziałem II. działu trzeciego Kodeksu Ochrona wynagrodzenia za pracę, również wskazują na cechy charakterystyczne dla tytułowego zagadnienia. Wypłat wynagrodzenia należy dokonywać co najmniej raz w miesiącu, w stałym i ustalonym terminie (art. $85 \S 1$ k.p.). Wynagrodzenie za pracę jest zatem świadczeniem okresowym, powtarzającym się, wypłacanym przynajmniej raz w miesiącu. Powyższe prowadzi do konstatacji, że wynagrodzeniu za pracę można nadać charakter ciągły, co wydaje się być zdeterminowane również istotą samego stosunku pracy, jako więzi łączącej pracownika $\mathrm{z}$ pracodawcą. Nadto pracodawca jest zobowiązany do wskazania pracownikowi częstotliwości dokonywania wypłat (art. 29 § 3 pkt 2 k.p.) ${ }^{17}$. Wynagrodzenie za pracę przybiera postać pieniężną (art. $86 \quad \S 2$ k.p.). Druga część przywołanego przepisu stanowi o możliwości częściowej wypłaty wynagrodzenia w innej formie niż forma pieniężna, jeśli taką możliwość przewidują ustawowe przepisy prawa pracy lub układ zbiorowy pracy. Wynagrodzenie za pracę jest zatem świadczeniem mającym wartość majątkową, wyrażaną przede wszystkim w pieniądzu, wypłacaną pracownikowi poprzez wydanie ustalonej $\mathrm{w}$ treści umowy o pracę sumy. Wypłata wynagrodzenia powinna nastąpić w walucie polskiej - krajowych środkach płatniczych według wartości nominalnej ${ }^{18}$.

Wyżej poczynione uwagi prowadzą do konstatacji, że w oparciu o przedstawione cechy charakterystyczne można wskazać na signum specificum wynagrodzenie za pracę w ujęciu Kodeksu pracy. Przede wszystkim wskazać należy, że wynagrodzenie za pracę jest obowiązkowym świadczeniem o charakterze bezwzględnym, wynikającym ze stosunku pracy (art. $22 \S 1$ k.p.).

Obowiązek terminowego i prawidłowego wypłacania wynagrodzenia za pracę jest jednym z podstawowych obowiązków pracodawcy. $\mathrm{Na}$ cechę obowiązkowości wynagrodzenia za pracę zwrócił uwagę Sąd Najwyższy, wskazując, że pracodawca, który nie

17 Zob. J. Żołyński, w: Kodeks pracy. Komentarz, red. J. Żołyński, Gdańsk 2016, s. 236.

18 J. Piątkowski, Aksjologiczne..., s. 169. 
wypłaca pracownikowi w terminie całości wynagrodzenia, ciężko narusza swój podstawowy obowiązek z winy umyślnej, choćby z przyczyn niezawinionych nie uzyskał środków finansowych na wynagrodzenia. Obowiązkiem pracodawcy jest bowiem terminowe wypłacanie wynagrodzeń, a nie uzyskiwanie na nie środków ${ }^{19}$. W innym judykacie Sąd Najwyższy wywiódł, że pracodawca nie może być zwolniony z obowiązku wypłacenia wynagrodzenia za pracę $\mathrm{z}$ tego powodu, że stanowi to dla niego nadmierne obciążenie finansowe ${ }^{20}$.

Charakter bezwzględności wynagrodzenia za pracę należy wywieść expressis verbis z normy stanowiącej o zakazie zrzeczenia się przez pracownika prawa do wynagrodzenia, jak również przeniesienia tego prawa na inną osobę (art. 84 k.p.). Tym samym czynność dokonana przez pracownika polegająca na zrzeczeniu się prawa do wynagrodzenia lub też przeniesieniu tego prawa na inną osobę, należy traktować jako czynność ex lege nieważną. Przy czym wskazać należy, że w przywołanej normie jest mowa o prawie pracownika do wynagrodzenia, czyli ekspektatywie - wierzytelności przypadającej, a nie pobranym już przez pracownika wynagrodzeniu za pracę. Wydaje się jednak, że w omawianym przepisie ustawodawcy zabrakło konsekwencji, skoro jest tu mowa "tylko" o wynagrodzeniu. Wydaje się bowiem, że skoro przepis ten został umiejscowiony w części Kodeksu dotyczącej ochrony wynagrodzenia za pracę, to celem przywołanej normy winna być ochrona właśnie wynagrodzenia za pracę. Na cechę bezwzględności wynagrodzenia za pracę wskazuje także Sąd Najwyższy, podnosząc, że nieważne jest zobowiązanie się pracownika, że w przyszłości nie będzie dochodził od pracodawcy tego wynagrodzenia za pracę (pactum de non petendo) ${ }^{21}$.

W końcu wskazać należy, że wynagrodzenie za pracę jest świadczeniem wynikającym ze stosunku pracy, bez względu na podstawę nawiązania tego stosunku. W świetle powyższego stwierdzić należy, że nazywane wynagrodzeniami za pracę świadczenia uzyskiwane $\mathrm{w}$ ramach zatrudnienia niepracowniczego nie są wynagrodzeniami za pracę w świetle Kodeksu pracy. Tym samym tylko w ramach zatrudnienia pracowniczego można mówić o wynagrodzeniu za pracę 22 .

Postać pieniężna wynagrodzenia za pracę jest formą podstawową (art. $86 \S 2$ k.p.) i trywializując moża wskazać, że zmierza ona do dokonania przesunięć majątkowych ze strony pracodawcy na rzecz pracownika. Wynagrodzenie za pracę zwiększa aktywa po stronie

\footnotetext{
${ }^{19}$ Wyrok Sądu Najwyższego z dnia 4 kwietnia 2000 r., I PKN 516/99, OSNP 2001, nr 16, poz. 516.

${ }^{20}$ Wyrok Sądu Najwyższego z dnia 11 stycznia 2006 r., II PK 113/05, LEX nr 211691.

${ }^{21}$ Wyrok Sądu Najwyższego z dnia 16 października 2009 r., I PK 89/09, OSNP 2011, nr 11-12, poz. 147.

${ }^{22}$ Podobne stanowisko prezentuje M. Nowak. Zob. M. Nowak, Wynagrodzenie..., s. 17.
} 
pracownika, przynosząc korzyści majątkowe ${ }^{23}$, ma charakter majątkowo-przysparzający, co pozwala odróżnić wynagrodzenie za pracę od innych świadczeń wynikających ze stosunku pracy.

Wynagrodzenie za pracę jest świadczeniem powtarzającym się, wypłacanym okresowo w ustalonych odstępach czasu (art. $85 \S 1$ k.p.). Powyższa cecha ma walor ochronny, nadto pozwala odróżnić wynagrodzenie za pracę od innych świadczeń, którym nie można przypisać charakteru periodyczności. Okresowy charakter wypłat wynagrodzenia za pracę wynika $\mathrm{z}$ istoty samego stosunku pracy, jako trwałej więzi prawnej o charakterze dwustronnie zobowiązującym ${ }^{24}$. W ocenie Sądu Najwyższego ochronie prawnej podlegają bieżące i zaległe wynagrodzenia za pracę bez względu na łączący strony stosunek prawny ${ }^{25}$. Tym samym wynagrodzenie za pracę nie traci charakteru świadczenia ze stosunku pracy przez fakt, że $\mathrm{w}$ chwili wystąpienia $\mathrm{z}$ roszczeniem o jego wypłatę strony nie pozostają już w stosunku $\operatorname{pracy}^{26}$.

Należy również podkreślić, że wynagrodzenie za pracę jest świadczeniem przysługującym pracownikowi za pracę wykonaną zasadniczo niewadliwie (art. 80). Zatem można $\mathrm{w}$ tym kontekście mówić o związku między wykonaną pracą a wynagrodzeniem za nią, co jest konsekwencją dwustronnie (wzajemnie) zobowiązującego charakteru stosunku pracy. W literaturze przedmiotu wskazuje się także na ekwiwalencyjność wynagrodzenia za pracę względem pracy. Ubocznie wskazać należy, że odnośnie do tej ostatniej cechy, zdania w literaturze przedmiotu są podzielone ${ }^{27}$. Nadto w doktrynie wskazuje się również na funkcję alimentarną ${ }^{28}$ czy funkcję bodźcową ${ }^{29}$ wynagrodzenia za pracę.

\section{Świadczenia inne niż wynagrodzenie za pracę w Kodeksie pracy}

Kodeks obok wynagrodzenia za pracę przewiduje inne świadczenia. Przewidziane w regulacji Kodeksowej świadczenia cechują się właściwościami odmiennymi od wynagrodzenia za pracę. Należy ogólnie scharakteryzować te świadczenia, aby wyeksponować zasadnicze różnice w stosunku do wynagrodzenia za pracę.

Wypłaty świadczeń za czas niewykonywania pracy zostały określone mianem wynagrodzenia (art. 80 zd. 2 k.p.). Tym samym na gruncie Kodeksu obok wynagrodzenia za pracę faktycznie wykonaną występują wynagrodzenia za czas niewykonywania pracy. Przy

\footnotetext{
${ }^{23}$ B. Wagner, Wynagrodzenie za pracę, Warszawa 1997, s. 20.

24 Zob. M. Święcicki, Prawo..., s. 30 i n.

25 Zob. Wyrok Sądu Najwyższego z dnia 14 października 1997 r., I PKN 319/97, OSNP 1998, nr 15, poz. 450.

${ }^{26}$ Tamże, teza 2. wyroku.

${ }^{27}$ B. Wagner, Wynagrodzenie ..., s. 1 i n.

${ }^{28}$ T. Liszcz, Prawo pracy..., s. 297.

${ }^{29}$ Zob. I. Różańska-Dorosz, Wynagrodzenie za pracę i inne świadczenia ze stosunku pracy, Wrocław 2003, s. 8.
} 
czym te "drugie" wynagrodzenia będą przysługiwać pracownikom tylko wtedy, gdy wynika to expressis verbis $\mathrm{z}$ przepisów prawa pracy ${ }^{30}$.

W nauce prawa pracy należności za czas niewykonywania pracy są określane jako wynagrodzenia gwarancyjne ${ }^{31}$, socjalne ${ }^{32}$ bądź jako wypłaty suspensyjne ${ }^{33}$. Podstaw ratio legis tak przyjętej konstrucji należy upatrywać w zapewnieniu pracownikom gwarancji otrzymania środków potrzebnych na zaspokojenie potrzeb w okresie niewykonywania pracy z przyczyn niezawinionych przez pracownika. Bez wątpienia jest to przejaw funkcji alimentarnej wynagrodzenia. Powyższe prowadzi do konstatacji, że wynagrodzenie jest świadczeniem wzajemnie-gwarancyjnym. $Z$ jednej strony bowiem przysługuje pracownikowi wynagrodzenie za pracę, która została faktycznie wykonana, z drugiej strony za czas niewykonywania pracy $\mathrm{w}$ sytuacjach wymienionych explicite $\mathrm{w}$ przepisach, pracownikowi przysługuje wynagrodzenie.

Do innych świadczeń niż wynagrodzenie za pracę Kodeks pracy zalicza: odprawy, odszkodowania i nagrody ${ }^{34}$. Przewidziane w przepisach Kodeksu odprawy przysługują pracownikom w sytuacji ustania stosunku pracy ${ }^{35}$. Przy czym mogą być wypłacane innym podmiotom niż pracownik ${ }^{36}$, co stanowi różnicę w stosunku do wynagrodzenia za pracę. Odszkodowania zasadniczo mają na celu wyrównać pracownikowi poniesione straty w jego majątku lub też doznane szkody ${ }^{37}$. Odmiennie w tym zakresie jest kształtowane odszkodowanie o zakazie konkurencji po ustaniu stosunku pracy, (art. $101^{2}$ k.p.). Tym samym, co do zasady odszkodowaniom nie można przypisać charakteru majątkowo-przysparzającego, który charakteryzuje wynagrodzenie za pracę. Nagrody zaś są zwieńczeniem szczególnego (ponad przeciętnego) wkładu pracownika w proces pracy, przy czym nagrody mają charakter uznaniowy $^{38}$ (art. 105 k.p.), co stanowi zasadniczą różnicę w stosunku do wynagrodzenia za pracę. Jednak wocenie Sądu Najwyższego nagroda jubileuszowa jest świadczeniem

30 Zob. art. 81 § 1 k.p., art. 92 § 1 k.p., art. 172 k.p. czy na zwolnienia okolicznościowe wynikające z rozporządzenia Ministra Pracy i Polityki Socjalnej z dnia 15 maja 1996 r. w sprawie sposobu usprawiedliwiania nieobecności w pracy oraz udzielania pracownikom zwolnień od pracy (tekst jedn.: Dz. U. z 2014 r. poz. 1632 ze zm.).

31 Tak K. Kolasiński, Prawo pracy i zabezpieczenia społecznego, Toruń 2003, s. 250 i n.

32 Tak H. Szurgacz, w: Prawo pracy. Zarys wykładu, red. Z. Kubot, T. Kuczyński, Z. Masternak, wyd. 3, Warszawa 2010, s. 198.

33 Zob. T. Liszcz, Prawo pracy..., s. 288.

34 Zob. odnośnie odpraw art. 75 w zw. z art. 74 k.p., art. $92^{1} \S 2$ k.p., art. 93 k.p.; odnośnie odszkodowań art. 45 $\S 1 \mathrm{w} \mathrm{zW} . \mathrm{z}$ art. $47^{1}$, art. 50, art. $56 \S 1 \mathrm{w} \mathrm{zW.} \mathrm{z} \mathrm{art.} \mathrm{58,} \mathrm{art.} \mathrm{59,} \mathrm{art.} 60$ k.p.; odnośnie nagród art. 105 k.p.

35 Zob. art. 75 w zw. $z$ art. 74 k.p., art. $92^{1} \S 2$ k.p., art. 93 k.p.;

36 Zob. zasady dotyczące wypłaty odprawy pośmiertnej - art. 93 k.p.

37 Zob. odszkodowanie $\mathrm{z}$ tytułu nieuzasadnionego lub niezgodnego z prawem wypowiedzenia umowy o pracę przez pracodawcę - art. $45 \S 1 \mathrm{w} \mathrm{zW.} \mathrm{z} \mathrm{art.} 47^{1}$, art. 50, art. $56 \S 1 \mathrm{w} \mathrm{zW.} \mathrm{z} \mathrm{art.} \mathrm{58,} \mathrm{art.} \mathrm{59,} \mathrm{art.} 60$ k.p.

38 Zob. D. Klucz, Problem dopuszczalności stosowania warunku na tle nagrody pracowniczej z art. $105 \mathrm{KP}$, „Monitor Prawa Pracy” 2015, nr 2, s. 62 i n. 
wynagrodzeniowym i przez to roszczeniowym, więc $\mathrm{w}$ istocie posiada charakter premii ${ }^{39}$. Wspólną cechą wyżej przedstawionych świadczeń jest to, że wynikają ze stosunku pracy, ale zasadniczo nie odwzajemniają pracy pracownika. Zatem, co do zasady, można przypisać im charakter autonomiczny w stosunku do pracy faktycznie wykonanej przez pracownika, co jest kolejną różnicą do wynagrodzenia za pracę. Należy zauważyć, że świadczenia te mają zasadniczo charakter jednorazowy, co stanowi kolejną różnicę w stosunku do wynagrodzenia za pracę.

\section{Uwagi końcowe}

W niniejszym opracowaniu została podjęta próba ukazania istoty wynagrodzenia za pracę w ujęciu Kodeksu pracy. Analizie poddano przepisy Kodeksu pracy wskazujące na istotne cechy odnoszące się do tytułowego zagadnienia, co z kolei pozwoliło zbudować "własną" definicję.

Wydaje się, że cechom pojęciowym wynagrodzenia za pracę wskazanym w niniejszym opracowaniu a wynikającym z Kodeksu pracy można przypisać charakter uniwersalny, bacząc na postanowienia wybranych pragmatyk pracowniczych w zakresie wynagrodzenia za pracę $^{40}$. Stwierdzić bowiem należy, że poszczególne normy wybranych pragmatyk nie zawierają definicji normatywnej wynagrodzenia za pracę, nadto nie wskazują jego cech. Natomiast w sprawach nieuregulowanych niektóre z nich odsyłają do postanowień Kodeksu pracy $^{41}$. Różnice można sprowadzić do poszczególnych składników, co stanowi już przedmiot odrębnych rozważań.

O uniwersalności wynagrodzenia można mówić, bacząc również na autonomiczne źródła prawa pracy. Uniwersalność w rozważanym kontekście należy rozumieć jako pewien minimalny pułap, pewną minimalną ilość cech, o których mowa w przywołanych przepisach Kodeksu, a które mogą zostać dodatkowo "wzbogacone" przez inne cechy zawarte w układach zbiorowych pracy czy regulaminach wynagradzania.

Pojęcie wynagrodzenia za pracę jest zatem pojęciem użytecznym dla wszystkich aktów, w tym również pozakodeksowych. Jest elementarną instytucją stosunku pracy, a przez to centralnym pojęciem prawa pracy. Zarówno w literaturze przedmiotu, jak w judykaturze,

39 Wyrok Sądu Najwyższego z dnia 14 maja 2012 r., I PK 174/11, „Gazeta Prawna” 2012, nr 129, s. 7.

40 Wybrane pragmatyki pracownicze: ustawa $\mathrm{z}$ dnia 26 stycznia 1982 r. Karta Nauczyciela (tekst jedn.: Dz.U. z 2016 r. poz. 1379 ze zm.), ustawa z dnia 27 lipca 2005 r. Prawo o szkolnictwie wyższym (tekst jedn.: Dz.U. z 2012 r. poz. 572 ze zm.), ustawa z dnia 21 listopada 2008 r. o pracownikach samorządowych (tekst jedn.: Dz.U. z 2016 r. poz. 902 ze zm.), ustawa z dnia 21 listopada 2008 r. o służbie cywilnej (tekst jedn.: Dz.U. z 2016 r. poz. 1345 ze zm.).

41 Zob. art. 91c ust. 1 Karty Nauczyciela, art. 136 ust. 1 Prawa o szkolnictwie wyższym, art. 43 ust. 1 ustawy o pracownikach samorządowych, art. 9 ust. 1 ustawy o służbie cywilnej. 
nie wypracowano dotąd jednolitego stanowiska odnośnie rozumienia pojęcia wynagrodzenia za pracę, zatem ustawodawca winien zamieścić definicję legalną omawianego pojęcia w Kodeksie pracy.

Należy zauważyć, że obecnie istotne cechy wynagrodzenia za pracę są rozproszone w różnych częściach Kodeksu i nie tworzą one explicite definicji nominalnej. Wcześniej, w literaturze przedmiotu, formułowano postulaty uregulowania w Kodeksie pracy definicji wynagrodzenia za pracę ${ }^{42}$. Obecnie również taki postulat jest wysuwany ${ }^{43}$.

Jak wskazano na wstępie, o wynagrodzeniu za pracę jest mowa w wielu naukach. W naukach prawnych - przepisach prawa proceduralnego, pozostających $\mathrm{W}$ związku z przepisami prawa materialnego również jest mowa o wynagrodzeniu za pracę. Przepisy proceduralne jednak zawierają definicję wynagrodzenia za pracę ${ }^{44}$, wskazującą na przykładowe świadczenia zaliczone do wynagrodzenia za pracę podlegającego zajęciu W sądowym postępowaniu egzekucyjnym, a która nie jest tożsama z tym znaczeniem, jakie można wyinterpretować z cech wskazanych w Kodeksie pracy.

Potrzeba normatywnego zdefiniowania wynagrodzenia za pracę wynika przede wszystkim ze względów praktycznych. Występują bowiem trudności z właściwym zakwalifikowaniem świadczeń ze stosunku pracy. Powstają wątpliwości, które z tych świadczeń podpadają pod pojęcie wynagrodzenia za pracę, a które z nich należą do innej kategorii. Do takiej konstatacji można dojść po lekturze sprawozdań z przeprowadzonych kontroli Państwowej Inspekcji Pracy. Jedną z przyczyn naruszeń przepisów w zakresie wypłat wynagrodzeń i innych świadczeń ze stosunku pracy jest niejasność obowiązujących przepisów dotyczących wynagrodzeń za pracę. Występują problemy w zakresie prawidłowej wykładni i stosowania przepisów Kodeksu odnoszących się zwłaszcza do ochrony wynagrodzenia za pracę ${ }^{45}$. Tym samym przepisy z zakresu ochrony wynagrodzenia za pracę tracą walor ochronny.

Należy zatem wysunąć postulat de lege ferenda uregulowania w przepisach Kodeksu pracy expressis verbis definicji wynagrodzenia za pracę. Należy żywić nadzieję, że

42 Zob. M. Święcicki, Prawo..., s. 5 i n., M. Seweryński, Wynagrodzenie..., s. 11 i n.

43 Główny Inspektor Pracy w Sprawozdaniu z działalności Państwowej Inspekcji Pracy w 2015 r., s. 115, https://www.pip.gov.pl/pl/f/v/156451/Sprawozdanie\%202015.pdf [dostęp: 20.09.2016 r.].

${ }^{44}$ Zob. art. art. $881 \S 2$ zd. 2 ustawy z dnia 17 listopada 1964 r. Kodeks postępowania cywilnego (tekst jedn.: Dz.U. z 2014 r., poz. 101 ze zm.) oraz art. art. 1a pkt 17 ustawy z dnia 17 czerwca 1966 r. ustawa o postępowaniu egzekucyjnym w administracji (tekst jedn.: Dz.U. z 2014 r. poz. 1619 ze zm.).

45 Zob. sprawozdania Głównego Inspektora Pracy z działalności Państwowej Inspekcji Pracy w roku 2010, s. 72 i n., w roku 2011, s. 71 i n., w roku 2012, s. 92 i n., w roku 2013, s. 86 i n., w roku 2014, s. 90 i n., https://www.pip.gov.pl/pl/o-urzedzie/sprawozdania-z-dzialalnosci [dostęp: 16.04.2016 r.]. 
w niedalekiej przyszłości ustawodawca w jasny, klarowny, niebudzący wątpliwości sposób zamieści w Kodeksie pracy prawną definicję wynagrodzenia za pracę. Dobrą okazją dla dokonania zmian w tym zakresie może być powołana niedawno Komisja Kodyfikacyjna Prawa Pracy, która ma przygotować nowy Kodeks pracy.

\section{Bibliografia:}

\section{Literatura}

Florek L., Zieliński T., Prawo pracy, Warszawa 2007

Goździewicz G., Refleksje na temat prawa do godziwego wynagrodzenia za prace, w: Wynagrodzenie za prace $w$ warunkach spotecznej gospodarki rynkowej i demokracji, red. W. Sanetra, Warszawa 2009

Klucz D., Problem dopuszczalności stosowania warunku na tle nagrody pracowniczej z art. $105 \mathrm{KP}$, „Monitor Prawa Pracy” 2015, nr 2

Kolańczyk K., Prawo rzymskie, Warszawa 2007

Kolasiński K., Prawo pracy i zabezpieczenia społecznego, Toruń 2003

Kopertyńska M.W., Motywowanie pracowników. Teoria i praktyka, Warszawa 2009

Kotarbiński T., Elementy teorii poznania, logiki formalnej i metodologii nauk, Wrocław-WarszawaKraków-Gdańsk-Łódź 1990

Liszcz T., Prawo pracy, Warszawa 2014

Nowak M., Wynagrodzenie za prace, red. Z. Góral, Warszawa 2014

Piątkowski J., Aksjologiczne i normatywne podstawy prawa stosunku pracy, Toruń 2013

Roszewska K., Wynagrodzenie i inne świadczenia ze stosunku pracy, Warszawa 1999

Różańska-Dorosz I., Wynagrodzenie za prace i inne świadczenia ze stosunku pracy, Wrocław 2003

Rycak M. B., Wronowska E., Rycak A., Prawo pracy repetytorium, Warszawa 2012

Seweryński M., Wynagrodzenie za pracę. Pojęcie, regulacja i ustalanie, Warszawa 1981

Skoczyński J., Prawo do godziwego wynagrodzenia, „Praca i Zabezpieczenie Społeczne” 1997, nr 4

Sobol E., Nowy słownik języka polskiego pwn, Warszawa 2002

Szubert W., Zarys prawa pracy, Warszawa 1976

Szurgacz H., w: Prawo pracy. Zarys wykładu, red. Z. Kubot, T. Kuczyński, Z. Masternak, wyd. 3, Warszawa 2010

Święcicki M., Prawo wynagrodzenia za prace, Warszawa 1963

Wagner B., Wynagrodzenie za prace, Warszawa 1997

Wagner B., Ekwiwalencyjność wynagrodzenia i pracy, „Praca i Zabezpieczenie Społeczne” 1996, nr 6

Wratny J., Minimalne wynagrodzenie za prace - nowe regulacje prawne, „Praca i Zabezpieczenie Społeczne" 2003, nr 6

Żołyński J., w: Kodeks Pracy. Komentarz, red. J. Żołyński, Gdańsk 2016

\section{Orzecznictwo}

Wyrok Sądu Najwyższego z dnia 4 kwietnia 2000 r., I PKN 516/99, OSNP 2001, nr 16, poz. 516 Wyrok Sądu Najwyższego z dnia 11 stycznia 2006 r., II PK 113/05, LEX nr 211691

Wyrok Sądu Najwyższego z dnia 16 października 2009 r., I PK 89/09, OSNP 2011, nr 11-12, poz. 147

Wyrok Sądu Najwyższego z dnia 14 października 1997 r., I PKN 319/97, OSNP 1998, nr 15, poz. 450

Wyrok Sądu Najwyższego z dnia 14 maja 2012 r., I PK 174/11, „Gazeta Prawna” 2012, nr 129, s. 7

\section{Źródla internetowe}

Sprawozdania Głównego Inspektora Pracy z działalności Państwowej Inspekcji Pracy w latach 2010 2014, https://www.pip.gov.pl/pl/o-urzedzie/sprawozdania-z-dzialalnosci [dostęp: 16.04 .2016 r.]

Sprawozdanie Głównego Inspektora Pracy z działalności Państwowej Inspekcji Pracy w 2015 r., https://www.pip.gov.pl/pl/f/v/156451/Sprawozdanie\%202015.pdf [dostęp: 20.09.2016 r.] 